\title{
Stakeholder perceptions in the factors constraining the development and implementation of public private partnerships in the Ugandan electricity sector
}

\author{
Emmanuel Akampurira \\ Department of Construction Economics and Management, University of Cape Town \\ David Root \\ Department of Construction Economics and Management, University of Cape Town
}

\author{
Winston Shakantu \\ Department of Construction Management (Building Sciences), Nelson Mandela Metropolitan University
}

\begin{abstract}
Amidst increasingly constrained public budgets and inadequate service delivery, private sector participation through public private partnerships is increasingly being used as a means for delivering physical infrastructure. The government of Uganda, which is currently grappling with a crippling electricity power deficit, has over the years, pursued a number of strategies to encourage private sector participation in the electricity sector, but with limited success. This paper presents the findings of research into the relative importance as perceived by sector stakeholders, of factors that hamstring private sector participation in the development of hydropower generation facilities through public private partnerships in Uganda. The stakeholders considered in this paper are those representing the government and private sector entities in the development of the partnerships. A review of literature and project documents enabled the identification of relevant factors. Data was collected from the respondents by means of a self administered structured questionnaire and quantitative methods used for data analysis. Key findings from the research indicate that the respondents regarded the regulatory and legal frameworks as being attractive for private sector participation and this business environment is further enhanced by their confidence in the government's commitment to honour its contractual obligations. In contrast, difficulties in structuring and obtaining finance together with issues over the cumbersome approval process and resistance from environmental groups were identified as the most significant constraints to the development and implementation of public private partnerships in the Ugandan electricity sector. Recognizing the importance of an adequate and reliable supply of power in Uganda, as in so many
\end{abstract}

other sub-Saharan countries, it is anticipated that the identification of the relative importance of the constraints as perceived by stakeholders, will inform the process of developing measures and strategies to mitigate the constraints thus facilitating the speedy implementation and deal closure of public private partnership initiatives with the ensuing benefits.

Keywords: public private partnerships, Uganda, electricity sector, investment

\section{Introduction}

The provision of an adequate and reliable physical infrastructure is important given the role it plays in supporting the growth of industry, delivery of social services, and enabling the movement of people and goods, amongst other factors. Physical infrastructure e.g. roads, telecommunication, electric power, and water and sanitation facilities, have long been identified as catalysts for triggering and sustaining economic growth (World Bank, 1994; Sader, 2000; Spoehr et al., 2002; Colin et al., 2004; Van, 2005) and more importantly, for developing countries, is the significant role infrastructure has to play in the attainment of the Millennium Development Goals (MDG's).

Traditionally the responsibility for the provision, management and financing of the development of physical infrastructure assets has lain within the ambit of governments, with financing being obtained from various taxation mechanisms imposed on the population, and in developing countries through bilateral and multilateral support (Bennet et al., 1999; Akintoye et al., 2003; Van, 
2005). With regard to the electricity sector in Uganda, this function, which included responsibility for generation, transmission and distribution of electricity, was undertaken by a state-owned utility company.

Uganda is a developing country located in subSaharan Africa with a population of 24.4 million people of whom an estimated $88 \%$ live in rural areas. Bilateral and multilateral budgetary support, in terms of grants and loans, accounts for $30 \%$ of the Ugandan government's budget for the financial year 2008/2009 (Suruma, 2008). The objective in the financial year $2008 / 2009$ is to achieve a GDP growth rate of at least $8 \%$ per annum (Suruma, 2008). In order to sustain the economic growth and improve the general standard and quality of living of its people, the government of Uganda in its energy policy of 2002 recognised the significant role played by an adequate and reliable supply of electricity (MoEMD, 2002).

Currently, hydropower is the major source of electricity for Uganda. The current installed hydropower generation capacity of $317 \mathrm{MW}$ is unable to meet the estimated current peak demand of 380 MW (MoEMD, 2002; ERA, 2008). The low level of power supply and hence low population coverage contrasts with the World Bank's estimate of $2500 \mathrm{MW}$ of hydropower generation potential (World Bank, 2005b). With the increase in energy demand estimated to grow at $4-5 \mathrm{MW}$ per month, and an economy growing at an average rate of $6.3 \%$ per annum for the last seven years, the need for additional power generation facilities has become critical (Engorait, 2004).

As a result, the government of Uganda has, in the recent past, promoted strategies to encourage and incentivise private sector participation in the development of hydropower generation facilities (Electricity Act, 1999; Engorait, 2004). Key to this was an electricity sector reform process that led to the unbundling of the previous vertically integrated state owned Uganda Electricity Board (UEB), creation of an independent regulatory body: and enacting of the Electricity Act 1999 that provides a legal framework for private sector participation (Electricity Act, 1999; Mugyenzi, 2001; Nyirinkindi, 2003; Engorait, 2004; GoU, 2004; Mbendi, 2006).

Notwithstanding the reforms and government commitment, private sector investment is still limited and many proposed projects have failed to materialise. A number of proposed public private partnership initiatives have been hampered by accusations of, inter alia; corruption (Sasha, 2003; World Bank, 2007), protracted negotiations (Government of Uganda, 2004; Bbumba, 2006), withdrawal of project developers (Energy Information Administration, 2004) and difficulties in structuring project financing (Bbumba, 2006).

The aim of this study was to identify potential constraints and their relative importance as perceived by stakeholders involved in the development and implementation of public private partnership projects for hydropower generation facilities in the Uganda electricity sector. The findings would inform the process of developing measures and strategies to mitigate the constraints thus facilitating the speedy implementation and deal closure of public private partnership initiatives with the ensuing benefits.

\section{Constraints to private sector participation}

A comprehensive literature review enabled the identification of twenty-three constraints to the development and implementation of public private partnerships in the energy sector of developing countries. These include: investors' need for a predictable investment environment (Lamech, 2003); clear and unambiguous regulatory and legislation processes that provide guidance as well as avenues of redress for aggrieved parties (ADB, 2000; Sader, 2000) and importantly the willingness of all participants to adhere to and respect the outcomes of these processes (ADB, 2000). Ambiguity within these processes often leads to investor apathy as evidenced in China (Blackman et al., 1999) or investors' reliance upon special situations and/or political patronage to obtain concessions often on a non-competitive basis (ADB, 2000).

In addition, political interference in contract awards as experienced with the Hwange project in Zimbabwe (Sader, 2000) and accusation of corruption and cronyism by a politically powerful family, for example, in the award of the Paiton and Tanjung Jati independent power producer tenders in Indonesia (Williams, 2006), have been identified as constraints to private sector participation in the electricity sector.

Restrictive conditions imposed by stringent regulations including the restriction on the project rate of return have acted as disincentives for the development of public private partnerships in Pakistan (Sader, 2000) and in China (Blackman et al., 1999). A Similar result has been obtained where there have been attempts to limit foreign ownership of private power companies (Jyoti et al., 1998; Blackman et al., 1999; Fraser, 2005; Woodhouse, 2005). In addition, delays in the electricity reform process (Blackman et al., 1999, Fraser, 2005) have acted as an impediment in that they delay the formation of an independent regulatory body; an important incentive for and a consideration of investors when deciding to invest in the electricity sector (Lamech, 2003).

Institutional challenges such as lengthy bureaucratic processes coupled with poor coordination between different public sector departments (Lamech, 2003), lack of, or non transparent project 
approval processes (Blackman et al., 1999), numerous requirements (Jyoti 1999; Sader, 2000) and low levels of skills/experience of personnel especially in the public sector (Moreldge et al., 1998; Bing $\mathrm{Li}$ et al., 2005), have variously been identified as significant constraints to the development of public private partnerships. These serve to increase lag time between project conception and implementation inevitably increasing the transaction costs involved.

Additional constraints identified and emanating from stakeholder pressure include: resistance to new developments by environmental organisations, a factor highly significant to hydropower projects (WCD , 2000) and public resistance, often stemming from an increase in the original heavily subsidised service charge (Hall et al., 2005).

With respect to project financing non-recourse financing mechanisms, that are dependant on a stream of revenue generated by the project when complete, are the norm for independent power producer schemes. As a result of the underdeveloped capital markets in many developing countries, obtaining long term finance from local financial institutions has been a challenge (Jyoti et al., 1998; $\mathrm{ADB}, 2000$ ) hence the frequent reliance on foreign capital both for debit and equity financing. This is a disincentive to investors in that it increases their exposure to foreign exchange risks that include availability, convertibility and transferability of money (Sader, 2000; ADB, 2000).

Attracting partners and project lenders to consortiums geared at developing private power projects has been further constrained by the poor creditworthiness of the power off-taker companies especially in single buyer models. A case in point is India where the perceived lack of credit worthiness of the state electricity boards and the additional reluctance of the government to provide guarantees to promoters led to the failure to reach deal closure on a number of independent power projects (Jyoti et al., 1998; ADB, 2000).

\section{Survey process}

The constraints identified from the literature review were incorporated into a questionnaire. The questionnaire consisted of two sections. The first section aimed at collecting information regarding the characteristics of the respondents and the second section soliciting their perceptions regarding the importance of the constraints to the development and uptake of public private partnerships for hydropower generation. The second section was designed in a five point Likert scale. A Likert style of questionnaire was chosen because of the advantages in regard to the elicitation respondent's extent of agreement or disagreement with a statement; facilitating the production of hierarchies of preferences of the respondents; and generating a hierarchy of preferences for different categories of respondents in the sampling space that can be compared (Fellows, 1997).

The target population consisted of managerial staff in government ministries, departments and private companies that have either expressed interest, or are involved in the development of PPP projects for hydropower generation in the electricity sector. The lack of a comprehensive reliable list of all participants in the development of hydropower projects through PPP necessitated the use of non-random sampling techniques. The respondents were identified through purposive and 'snowballing' sampling techniques. To check the suitability, clarity and appropriateness of the questions, drafts of the questionnaires were discussed with practitioners all having experience with the development of hydropower projects through public private partnerships. The questionnaire was subsequently refined.

The targeted population was contacted prior to delivering the questionnaire to ensure their willingness to participate in the survey. A total of fifty one (51) self administered questionnaires where delivered by hand to the respondents. Sixteen (16) questionnaires where administered to respondents from the private companies and thirty five (35) questionnaires to respondents from different government bodies / ministries. Twenty eight valid responses were returned, representing a response rate of $54.9 \%$. The respondents consist of $19(67.9 \%)$ from the government sector and $9(32.1 \%)$ from the private sector.

\section{Data analysis}

The data collected was analysed using SPSS. The reliability of the five point Likert scale used in the survey questionnaire was tested for internal consistency using the Cronbach's coefficient alpha $\alpha$. Values of $\alpha \geq 0.7$ are an acceptable indication of the reliability of the scale. A value of cronbach's alpha $\alpha=0.8231$ was obtained indicating good reliability of the scale.

The overall ranking of the constraints by the respondents was obtained by the mean score method (Chan et al., 2003; Shaokai Lu et al., 2007). The mean score (MS) for each constraint was calculated using the formulae:

$$
\begin{gathered}
\mathrm{MS} \\
=\sum(\mathrm{f} \times \mathrm{s}) \\
\mathrm{N}
\end{gathered}
$$

\section{Where}

$\mathrm{f}=$ frequency of response to each rating (1-5) for each constraint;

$\mathrm{s}$ = Score given to each constraint by the respondents, ranging from 1 for Strongly disagree to 5 for Strongly agree;

$\mathrm{N}$ = Number of responses to that constraint. 
In cases of the occurrence of a tie, a criterion for ranking was obtained based on the percentage of respondents strongly agreeing to the identified constraint.

Kendall's coefficient of concordance $w$ analysis was done to measure the degree of agreement of the respondents within a category on their ranking of the constraints. An acceptable degree of consensus to the ranking of the constraints exists among the respondents in that category if Kendall's coefficient of concordance $(w)$ is significant at the $5 \%$ level (Siegel et al., 1988; Field, 2005).

The Mann-Whitney $U$ test was then done to determine whether the mean ranks for each constraint are equal between the government and private sector respondents. A p value lower than 0.05 on the Mann-Whitney $U$ test serves to show that the null hypothesis of no difference between the mean ranks can be rejected indicating that there is a difference in perception between the respondents as regards the identified constraint (Siegel et al., 1988; Field, 2005).

To complement this, a Spearman rank correlation coefficient $\left(r_{s}\right)$ test was done to measure the agreement between the two respondent groups on their ranking of constraints in the uptake of PPP in the electricity sector. An association in the rankings by the respondents is indicated by $\mathrm{rS}$ being significant at level of 0.05 i.e. if $r_{S}>0.05$, there is no significant disagreement between the respondents on the ranking of the constraints to PPP (Siegel et al., 1988; Field, 2005).

\section{Survey results and analysis}

Table 1 presents the results of tests for Kendall's coefficient of concordance $(\mathrm{w})$ and the ranking of the constraints as perceived by the respondents. Kendall's coefficient of concordance (w) for the ranking of constraints among all the respondents is $0.298,(\mathrm{w})=0.328$ among the government sector respondents, and 0.365 among the private sector respondents. These Kendall's coefficients of concordance are all significant at the 0.000 level and therefore it can be concluded that there is a reasonable degree of agreement among the respondents in each of these groups and all respondents regarding the ranking of the constraints in public private partnerships in the electricity sector in Uganda.

In order to statistically compare the perceptions of the two respondent categories, the Mann-

Table 1: Ranking of constraints and Kendall's coefficient of concordance (w)

\begin{tabular}{|c|c|c|c|c|c|c|}
\hline \multirow[b]{2}{*}{ Constraint } & \multicolumn{2}{|c|}{ All respondents } & \multicolumn{2}{|c|}{ Government } & \multicolumn{2}{|c|}{ Private sector } \\
\hline & Mean & Rank & Mean & Rank & Mean & Rank \\
\hline Inability of local Institutions to provide equity financing & 4.17 & 1 & 3.74 & 4 & 4.78 & 1 \\
\hline Many requirements to obtain project approval & 3.55 & 2 & 3.84 & 1 & 4.22 & 3 \\
\hline Lengthy project approval process & 3.45 & 3 & 3.79 & 3 & 4.11 & 5 \\
\hline Delays as a result of lengthy bureaucratic procedures & 3.67 & 4 & 3.74 & 5 & 4.11 & 4 \\
\hline Resistance from Environmental groups & 3.83 & 5 & 3.79 & 2 & 3.78 & 6 \\
\hline Poor coordination between Government departments & 3.69 & 6 & 3.37 & 6 & 4.33 & 2 \\
\hline Low level of skills of personnel involved with PPP & 3.21 & 7 & 3.11 & 7 & 3.33 & 10 \\
\hline Resistance from Civil society organisations & 3.02 & 8 & 3 & 9 & 3.11 & 16 \\
\hline Poor creditworthiness of power off taker & 3.07 & 9 & 3.05 & 8 & 2.89 & 17 \\
\hline Investors concerns for need of intensive managerial resources & 2.90 & 10 & 2.89 & 10 & 3.11 & 13 \\
\hline Political interference in procurement process & 3.29 & 11 & 2.63 & 11 & 3.56 & 9 \\
\hline Weak regulatory framework lacking in clarity and ambiguous & 2.71 & 12 & 2.42 & 14 & 3.67 & 8 \\
\hline Slow implementation of power sector reforms & 2.57 & 13 & 2.26 & 16 & 3.67 & 7 \\
\hline Restrictions on the return on investment & 2.64 & 14 & 2.47 & 13 & 3.11 & 16 \\
\hline Accusations of corruption and corrupt tendencies & 2.71 & 15 & 2.47 & 12 & 2.78 & 19 \\
\hline Public resentment as a result of tariff increases & 2.60 & 16 & 2.32 & 15 & 3.11 & 14 \\
\hline Lack of an enabling regulatory framework & 2.40 & 17 & 2.11 & 21 & 3.22 & 11 \\
\hline Lack of political will and support & 2.86 & 18 & 2.21 & 18 & 2.89 & 18 \\
\hline Investors concerns of foreign exchange risk & 2.64 & 19 & 2.11 & 20 & 3.11 & 12 \\
\hline Lack of independence of regulatory body & 2.57 & 20 & 2.16 & 19 & 2.78 & 20 \\
\hline Lack of an enabling legal framework & 2.45 & 21 & 2.21 & 17 & 2.44 & 23 \\
\hline Failure of government to honour its contract obligations & 2.14 & 22 & 1.95 & 22 & 2.56 & 22 \\
\hline Restrictions on the level of foreign ownership of companies & 2.05 & 23 & 1.79 & 23 & 2.67 & 21 \\
\hline Kendall's coefficient of concordance w & \multicolumn{2}{|c|}{0.298} & \multicolumn{2}{|c|}{0.328} & \multicolumn{2}{|c|}{0.365} \\
\hline Level of significance & \multicolumn{2}{|c|}{0.000} & \multicolumn{2}{|c|}{0.000} & \multicolumn{2}{|c|}{0.000} \\
\hline
\end{tabular}


Table 2: Mann Whitney U test

\begin{tabular}{|c|c|c|c|}
\hline \multirow[b]{2}{*}{ Constraints } & \multicolumn{2}{|c|}{ Mean rank } & \multirow[b]{2}{*}{$\begin{array}{c}\text { Mann-Whitney } \\
\text { U test }\end{array}$} \\
\hline & Government & Private sector & \\
\hline Lack of an enabling regulatory framework & 12.21 & 19.33 & 0.02 \\
\hline Weak regulatory framework lacking in clarity and ambiguous & 12.00 & 19.78 & 0.02 \\
\hline Slow implementation of power sector reforms & 11.91 & 19.83 & 0.01 \\
\hline Lack of independence of regulatory body & 12.95 & 17.78 & 0.11 \\
\hline Many requirements to obtain project approval & 13.63 & 16.33 & 0.39 \\
\hline Lengthy project approval process & 13.71 & 16.71 & 0.43 \\
\hline Restrictions on the return on investment & 12.79 & 18.11 & 0.93 \\
\hline Restrictions to the level of foreign ownership of companies & 12.47 & 18.78 & 0.04 \\
\hline Poor coordination between Government departments & 12.63 & 18.44 & 0.07 \\
\hline Delays as a result of lengthy bureaucratic procedures. & 13.39 & 16.83 & 0.27 \\
\hline Low level of skills of personnel Involved with PPP & 14.03 & 15.5 & 0.64 \\
\hline Accusations of corruption and corrupt tendencies & 13.84 & 15.89 & 0.51 \\
\hline Resistance from Environmental groups & 14.87 & 13.72 & 0.70 \\
\hline Resistance from civil society organisations & 14.37 & 14.78 & 0.90 \\
\hline Public resentment as a result of tariff increases & 12.76 & 18.17 & 0.08 \\
\hline Investors concerns for need of intensive managerial resources. & 14.13 & 15.28 & 0.72 \\
\hline Political interference in procurement process & 12.50 & 18.72 & 0.05 \\
\hline Lack of political will and support. & 13.00 & 17.67 & 0.14 \\
\hline Lack of enabling legal framework. & 13.63 & 16.33 & 0.37 \\
\hline Failure of government to honour its contract obligations & 12.89 & 17.89 & 0.11 \\
\hline Investors concerns of foreign exchange risk & 11.97 & 19.83 & 0.01 \\
\hline Inability of local institutions to provide equity financing & 12.29 & 19.17 & 0.03 \\
\hline Poor creditworthiness of power off taker & 14.68 & 14.11 & 0.86 \\
\hline
\end{tabular}

Whitney test was conducted and the results shown in Table 2 indicate that there is general consensus of perception as regards the importance of the identified constraints to the implementation of public private partnerships $(0.01 \leq p \leq 0.93$ at $5 \%$ significance level). However, there is a difference in perception between the two groups i.e. $(p<0.05)$ with regard to 'Lack of an enabling environment', 'Weak regulatory environment lacking in clarity and ambiguous', for both $\mathrm{p}=0.02$, 'Slow implementation of power sector reforms' and 'investor concerns of foreign exchange risk' both with $\mathrm{p}=0.01$; 'restrictions to level of foreign ownership of companies' and 'reluctance of local institutions to provide equity financing' having $\mathrm{p}=0.04$ and 0.03 respectively.

To test whether there is agreement between the private and government sector respondents as to the ranking of constraints, Spearman's correlation coefficient ( $\mathrm{rs}$ ) was determined. A correlation coefficient (rs) of 0.717 was obtained (see Table 3). Therefore, the null hypothesis of no significant disagreement between the private and government sector respondents on the ranking of the constraints to private sector investment in the Uganda electricity sector has to be accepted. This implies with $99 \%$
Table 3: Spearman's rank correlation coefficient

\begin{tabular}{lccc}
\hline & & Government & Private \\
\hline Government & $\mathrm{r}_{\mathrm{s}}$ & 1.000 & 0.717 \\
& Significance & $\mathrm{NS}$ & 0.000 \\
\hline Private & $\mathrm{r}_{\mathrm{s}}$ & 0.717 & 1.000 \\
& Significance & 0.000 & $\mathrm{NS}$ \\
\hline
\end{tabular}

confidence that there is significant agreement on the ranking of constraints between the private and government sector respondents.

\section{Discussion of survey results}

An analysis of the ranking in terms of importance of the constraints brings to the forefront the challenge posed by the failure to access the necessary long term financing from local financial institutions. The difficulty in raising financing identified in this study has been similarly identified as a significant hindrance to private sector participation in power infrastructure development in developing countries (Jyoti et al., 1998; ADB, 2000; Sader, 2000), and public private partnerships generally (Akerele et al., 2003).

The respondents identify the need to obtain var- 
ious approvals (ranked 2) at different steps of the process as a significant constraint to development of PPP's. This is further exacerbated by the bureaucratic nature of the system (ranked 3) that causes delays, a situation that is not helped considering that quite often there is poor coordination between the government departments; an item that was ranked fourth in terms of importance.

Furthermore, and in a clear reflection of the situation in Uganda, the respondents ranked 'pressure from environmental groups' among the top five constraints to the development of hydropower stations through the PPP route. Environmentalists have been opposed to and instrumental in the delayed take off of a number of proposed projects (Sasha, 2003; World Bank, 2007).

On the other hand, the legal and regulatory framework is considered by the respondents to be conducive for private sector participation - a finding illustrated by the low ranking as constraints accorded to the items 'lack of enabling regulatory framework' (ranked 17), 'lack of independence of the regulatory body' (ranked 20) and 'lack of enabling legal framework' (ranked 21). Confidence in the Ugandan government's policy encouraging private sector participation is further illustrated with the respondents' low ranking of 'failure of government to honour its contract obligation,' (ranked 22).

While corruption has been suggested as a significant constraint to the development and implementation of public private partnerships in the electricity sector in Uganda (Sasha, 2003; Engorait, 2004; Bbumba, 2006; Mbendi, 2006), the respondents in this survey did not rank it highly.

The Mann-Whitney test shows that not all the perception regarding the relative importance of the identified factors as constraints to PPP's are the same between the private and government sector respondent categories. In relation to item 'lack of an enabling regulatory environment,' the $\mathrm{Z}$ ratio for the above item is -2.30 with an observed significance of 0.02 . The mean ranks for the two respondent groups on this item are private sector (19.33) and government sector (12.21). Likewise, for item 'weak regulatory environment lacking in clarity and ambiguous,' the mean ranks are private sector (19.78) and government sector (12.00). The significance is 0.02 and $Z$ ratio for the item is -2.44 . The results suggest that the private sector respondents are more sensitive to any shortcomings in the regulatory environment. This view is comparable to that available in the literature (Sader, 2000; Fraser, 2005; Woodhouse, 2005; William et al., 2006). Similarly, the two categories of respondents statistically differed on the item 'slow implementation of power sector reforms,' with the private sector respondents more conscious of this factor as a constraint to the implementation of PPPs. From Table 2 , it is observed that the level of significance for this factor is 0.01; the mean ranks are 19.83 and 11.91 for the private and government sector respondents respectively. The Z- ratio on this item is -2.48 .

As deduced from the results of the MannWhitney test, the difference in roles when structuring a PPP is illustrated in the difference in perception of importance between the key players. The private and public sector on the factors of 'investors concern for foreign exchange risk' where $\mathrm{Z}$ ratio is 2.54 and mean ranks are private sector (19.83) and government (11.97); similarly 'inability of local financial institutions to provide financing' $Z$ ratio is -2.24 and mean ranks are private sector (19.17) and government (12.29). Private sector respondent's greater awareness of these two factors as constraints stems from the greater responsibility they have in structuring the project financing and ensuring viability and profitability of the venture.

\section{Conclusions}

The review of literature enabled the identification of constraints to the development and implementation of public private partnerships in the electricity sector that have been experienced worldwide. These were incorporated into a survey questionnaire aimed at determining the relative importance of the identified constraints as perceived by the public and private sector promoters of public private partnerships in the Ugandan electricity sector. The results show that; in order, the following were identified as the most significant constraints to the development of public private partnerships:

1. Inability of local institutions to provide equity financing;

2. Many requirements to obtain project approval;

3. Lengthy project approval process;

4. Delays as a result of lengthy bureaucratic procedures;

5. Resistance from Environmental groups; and

6. Poor coordination between Government departments.

On the other hand, and starting with the least important, the following factors were considered to be of less importance - it should be recognised that although ranked low, it does not mean that the constraints below are totally absent in the Ugandan electricity sector.

1. Restrictions to the level of foreign ownership of companies;

2. Failure of government to honour its contract obligations;

3, Lack of an enabling legal framework;

4. Lack of independence of a regulatory body; and

5. Investors concerns of foreign exchange risk.

The findings from the study are valuable in the process of identifying strategies and measures to facilitate the speedy implementation and deal closure of public private partnerships. In addition, the findings provide an insight into the kind of con- 
straints to public private partnerships; information that is beneficial to countries planning to or undertaking similar ventures in the electricity sector.

\section{References}

ADB (2000), Developing best practices for promoting private sector investment in infrastructure, Asian Development Bank.

Ahadzi, M. (2001), The Private Finance Initiative: The procurement process in perspective. 17th annual ARCOM Conference 5-7 September, University of Salford. Vol. 1, 991-9.

Ahadzi, M. and Bowles, G. (2004), Public Private Partnerships and contract negotiations: An empirical study. Construction Management and economics Vol. 22 (9) Pg 967-978.

Akerele, D. and Gidado, K. (2003), The risks and constraints in the implementation of PFI/PPP in Nigeria. 19th Annual ARCOM Conference, 3-5 September, University of Brighton. Association of Researchers in Construction Management. Vol. 1, 379-91.

Akintoye, A. and Li, B. (2003), Public Private Partnership: Managing Risks and opportunities, An overview of Public Private Partnership, Blackwell Science.

Alison, B. (2002), Hydropower potential and development activities. Energy Policy, 30 1231-1239.

Bbumba, S. (2006), Power crisis: MP Okello was wrong, Sunday Monitor, Kampala, 15/01/06, www.monitor. co.ug, Accessed 15/01/06.

Bennet, E.,Grohmann, P. and Gentry, B. (1999), PublicPrivate Partnerships for the Urban Environment: Options and Issues, PPPUE Working Paper Series, UNDP/PPPUE \& Yale University.

Benoit, P. (2005), A Snapshot of PPI in Sub-Saharan Africa's Power Sector, Available online: www.ppiaf. org/FinalReportActivityPages/PPIAfricaConference, Accessed March 282006.

Bing Li,Akintoye, A. and Edwards, P. J. (2005) Critical success factors for PPP/PFI projects in the UK construction industry. Construction Management and Economics, 23 459-471.

Blackman, A. and Wu, X. (1999), Foreign Direct investment in China's power sector: trends, benefits and barriers. Energy Policy, 27 (12) pg 695-711.

Chan, P. C., Albert, Chan, W. M., Daniel and Ho, S. K. (2003), An empirical study of the benefits of construction partnering in Hong Kong. Construction Management and Economics, 21 Pg. 523 -533.

Chege, L. (2004), Attracting Investors into Private Infrastructure Investment in Emerging Markets, Available online: www.csir.co.za/akani Accessed 15 August, 2006.

Colin, K.,Parker, D. and Yin-Fang, Z. (2004), Foreign Direct Investment in infrastructure in developing countries: Does regulation make a difference? Asian Development Bank Institute (ADBI) Annual Conference on 'Infrastructure and Development: Poverty, Regulation and Private Sector Development'.
ERA, 2008, Constraints to investment in Uganda's electricity generation industry: www.era.or.ug/Pdf/ReportInvestments-Constraints_final_23-10-2008.pdf Accessed 20 January 2009.

Energy Information Administration (2004), Great lakes Region, Burundi, Kenya, Rwanda, Tanzania and Uganda, www.eia.doe.gov/emeu/cabs/eafrica.html, July 15.

Engorait, S. P. (2004), Power sector reforms in Uganda: Meeting the challenge of increased private sector investments and increased electricity access among the poor, Available Online: www.afrepren.org/ Pubs/esr.htm, Accessed 25 July 2006.

Field, A. (2005), Discovering Statistics using SPSS, 2nd Edition, London, Sage Publications Ltd.

Fraser (2005), Lessons from the Independent Private Power Experience in Pakistan. Energy and Mineral sector Board discussion Paper No. 14, (14)

GoU (2004), Annual Report 2004, Ministry of Energy and Mineral Development, Government of Uganda,

Government of Uganda (2004), Annual Report 2004, Ministry of Energy and Mineral Development, Government of Uganda.

Harris, C. (2003), Private Participation in Infrastructure in Developing Countries; Trends Impacts, and Policy lessons, World Bank working paper No 5.

Izzaguire, T. (2000), Trend in private investment in the energy sector 1990-99: Private participation Energy, Energy services for the world poor, World Bank and Energy sector management assistance programme.

Jyoti, P., G and Sravat, A., K (1998), Development and project financing of private power projects in developing countries: a case study of India. International Journal of Project Management 16 (2) Pg 99-105.

Lamech, R. and Kazim, S. (2003), What international investors look for when investing in developing countries: Results from a survey of international investors in the power sector, Energy and Mineral sector Board discussion Paper No. 06 The World Bank: Energy and Mining Sector Board.

Leedy, P. D. and Ormrod, J. E. (2005), Practical Research: Planning and design, New Jersey, Pearson Prentice Hall.

Mbendi (2006), Uganda Electrical power, www.mbendi. co.za/indy/powr/af/ug/p0005.htm Accessed 23 July, 2006.

MoEMD (2002), The Energy Policy for Uganda, Ministry of Energy and Mineral Development. The Republic of Uganda.

Mugyenzi, J. (2001), Reforming power sector in Africa; Power sector reform in Uganda. Proceedings of a National policy seminar, AFREPEN Occasional paper No 8.

Nyirinkindi (2003), Uganda's Electricity Sector in Transition; Paving the Ground for Future Demands. ESI Africa Total Coverage of African power industry, Issue 2.

Sader, F. (2000), Attracting Foreign direct investment into infrastructure, Foreign Investment Advisory Services occasional paper 12, The International Finance Corporation and World Bank.

Sasha, L. (2003), AES backs out of Bujagali dam project, 
www.corpwatch.org/article.php?id=8250, 14/07/06.

Shaokai Lu and Yan, H. (2007), An empirical study on incentives of strategic partnering in China: Views from construction companies. International Journal of Project Management, 25241 - 249.

Siegel, S. and Castellan John (1988), Nonparametric Statistics for the behavioural Sciences, 2nd Edition, McGRAW-HILL Book Company.

SO (2000), Public Private Partnerships: The Government's Approach, The Stationery office, London.

Spoehr, J.,Whitfield, D.,Sheil, C.,Quiggin, J. and Davidson, K. (2002), Partnership Privatisation and the Public Interest, Public Private Partnerships and the Financing of Infrastructure Development in South Australia, Centre for Labour Research, University of Adelaide, Australia.

Suruma, E. (2008), Budget Speech 2008/2009, Ministry of Finance Planning and Economic Development. Online at www.monitor.co.ug/resources/Budget\% 202007-08.pdf, Accessed 17 June, 2007.

Van, R. J. (2005), Financing infrastructure, Indevelopment.

William, J. H. and Ghanadan, R. (2006), Electricity reform in developing and transition countries: A reappraisal. Energy Vol. 31 Pg 815-844.

Woodhouse, E., J, (2005) The Experience with Independent Power Projects in Developing Countries: Interim Report, Program on Energy and Sustainable Development, Stanford University.

World Bank (1994), World Development Report 1994: Infrastructure for development, World Bank, Oxford University Press, New York.

World Bank (2005b), Uganda Country Brief 2005, Available online http://web.worldbank.org/ WBSITE/ EXTERNAL/COUNTRIES/AFRICAEXT/UGANDAEXTN, Accessed 06 June, 2006.

World Bank (2007), Uganda Bujagali hydropower project, Available Online http://web.worldbank.org, Accessed 12 July, 2007.

Received 7 February 2008; revised 13 April 2009 